\title{
Globally regional life cycle analysis of automotive lithium-ion nickel manganese cobalt batteries
}

\author{
Jarod C. Kelly ${ }^{1}$ (D) Qiang Dai ${ }^{1} \cdot$ Michael Wang ${ }^{1}$ \\ Received: 17 April 2019 / Accepted: 13 May 2019/Published online: 28 August2019 \\ (C) The Author(s) 2019, corrected Publication, May 2020
}

\begin{abstract}
Electric vehicles based on lithium-ion batteries (LIB) have seen rapid growth over the past decade as they are viewed as a cleaner alternative to conventional fossil-fuel burning vehicles, especially for local pollutant (nitrogen oxides $\left[\mathrm{NO}_{\mathrm{x}}\right]$, sulfur oxides $\left[\mathrm{SO}_{\mathrm{x}}\right]$, and particulate matter with diameters less than 2.5 and $10 \mu \mathrm{m}\left[\mathrm{PM}_{2.5}\right.$ and $\left.\mathrm{PM}_{10}\right]$ ) and $\mathrm{CO}_{2}$ emissions. However, LIBs are known to have their own energy and environmental challenges. This study focuses on LIBs made of lithium nickel manganese cobalt oxide (NMC), since they currently dominate the United States (US) and global automotive markets and will continue to do so into the foreseeable future. The effects of globalized production of NMC, especially $\mathrm{LiNi}_{1 / 3} \mathrm{Mn}_{1 / 3} \mathrm{Co}_{1 / 3} \mathrm{O}_{2}$ (NMC111), are examined, considering the potential regional variability at several important stages of production. This study explores regional effects of alumina reduction and nickel refining, along with the production of NMC cathode, battery cells, and battery management systems. Of primary concern is how production of these battery materials and components in different parts of the world may impact the battery's life cycle pollutant emissions and total energy and water consumption. Since energy sources for heat and electricity generation are subject to great regional variation, we anticipated significant variability in the energy and emissions associated with LIB production. We configured Argonne National Laboratory's Greenhouse gases, Regulated Emissions, and Energy use in Transportation (GREET®) model as the basis for this study with key input data from several world regions. In particular, the study examined LIB production in the US, China, Japan, South Korea, and Europe, with details of supply chains and the electrical grid in these regions. Results indicate that 27-kWh automotive NMC111 LIBs produced via a European-dominant supply chain generate $65 \mathrm{~kg} \mathrm{CO}_{2} \mathrm{e} / \mathrm{kWh}$, while those produced via a Chinese-dominant supply chain generate $100 \mathrm{~kg} \mathrm{CO} \mathrm{CO}_{2} \mathrm{e} / \mathrm{kWh}$. Further, there are significant regional differences for local pollutants associated with LIB, especially $\mathrm{SO}_{\mathrm{x}}$ emissions related to nickel production. We find that no single regional supply chain outperforms all others in every evaluation metric, but the data indicate that supply chains powered by renewable electricity provide the greatest emission reduction potential.
\end{abstract}

Keywords Lithium ion battery $\cdot$ Life cycle assessment $\cdot$ Automotive $\cdot$ Supply chain

Jarod C. Kelly

jckelly@anl.gov

1 Argonne National Laboratory, 9700 South Cass Avenue, Lemont, IL 60439, USA 


\section{Introduction}

Vehicles that use lithium-ion batteries (LIB) either exclusively, as in the case of battery electric vehicles (BEVs), or in combination with a conventional engine, as in the case of plug-in hybrid electric vehicles (PHEV), have experienced rapid growth over the past decade (International Energy Agency 2018). Efforts to increase their use, stemming from numerous worldwide government policies, suggest that this growth will likely continue (Stephens et al. 2018). The impetus for this movement is the potential for these vehicles to reduce both local pollutants such as nitrogen oxides $\left(\mathrm{NO}_{\mathrm{x}}\right)$, sulfur oxides $\left(\mathrm{SO}_{\mathrm{x}}\right)$, and particulate matter with diameters less than 2.5 and $10 \mu \mathrm{m}\left(\mathrm{PM}_{2.5}\right.$ and $\left.\mathrm{PM}_{10}\right)$, which have adverse human health effects, and $\mathrm{CO}_{2}$, for which many countries have set reduction targets. Despite the potential use-phase energy and emission reductions afforded by electric vehicles (EV) reported in literature (Notter et al. 2010; Faria et al. 2013; Hawkins et al. 2013; Bauer et al. 2015; Elgowainy et al. 2016), previous life cycle analyses (LCAs) of LIBs have found LIB manufacturing and its pertinent upstream processes to be associated with substantial energy and environmental impacts (Majeau-Bettez et al. 2011; Ellingsen et al. 2014; Kim et al. 2016). In addition to energy and air pollutant emission effects, LIB manufacturing is associated with water consumption that can have important regional differences in both its absolute quantity and the relative stress that it imposes on a localized water system. Water consumption is highly influenced by regional electricity production profiles (Lee et al. 2018).

We recently identified two LIB constituents - the active cathode material and aluminumtogether with energy use for cell assembly as key contributors to the cradle-to-gate energy and environmental impacts of LIBs. Moreover, we found that the LCA results for LIB depend to a large extent on the battery supply chain. The high energy demands for producing battery materials and constructing the cells make the energy and environmental impacts susceptible to electricity mix and heat sources, as well as battery material mining and refining activities, which exhibit considerable variations across geographic regions (Dai et al. Submitted).

The regional variations in EVs have been explored in previous LCA studies (Onat et al. 2015; Peterson et al. 2011; Nealer et al. 2015; Holland et al. 2016). However, these studies focused on the electric grid that powers the EVs over their use-phase. The regional variations in LIB manufacturing and upstream material mining and refining processes, and their impact on LIB LCA, remain to be understood. Although many of the battery materials are global commodities, the raw materials are usually sourced from different countries (Olivetti et al. 2017). In addition, LIBs are currently manufactured in dozens of plants scattered throughout Asia, America, and Europe, while a handful of LIB factories with production capacities greater than 5 GWh per year are expected to be built in China, South Korea, Hungary, Poland, and Sweden (Lutsey et al. 2018). As the world ramps up LIB production, the global LIB supply chain is likely to become more dynamic and geographically diverse. Understanding the global regionalism of LIB manufacturing and its effect on battery LCA is therefore crucial to sustainable battery supply chain development and EV deployment.

In this article, we explore the supply chain of automotive LIB production based on the $\mathrm{LiNi}_{1 / 3} \mathrm{Mn}_{1 / 3} \mathrm{Co}_{1 / 3} \mathrm{O}_{2}$ (NMC111) chemistry, because it is currently the most widely used in passenger EVs on the global market (Pillot 2018). According to Pillot, NMC accounted for $30 \%$ of the global cathode material demand for LIB for all applications in 2017 with a concentration in the automotive market, and NMC111 accounted for about $50 \%$ of the 
NMC demand. We examine the energy and environmental effects of production in regions where the NMC111 LIB and pertinent upstream materials are currently or planned to be made. In addition, for some production stages, we examine the effects of individual technologies such as electricity produced exclusively from coal, hydropower, or other renewable sources. We also consider $\mathrm{CF}_{4}$ and $\mathrm{C}_{2} \mathrm{~F}_{6}$ emissions in aluminum production and the effect of energy sources in cell assembly. From a regional perspective, we evaluate LIB production in the United States (US), China, Japan, South Korea, and Europe with details of supply chains and electrical grids in these regions.

\section{Methodology and basis}

This study uses the Greenhouse gases, Regulated Emissions, and Energy use in Transportation (GREET®) model to determine the effect of changes to the regional conditions of battery production on the energy and environmental impacts of batteries. In particular, the study considered multiple electrical grid profiles for the production stages of several materials. The materials and stages in question are presented in Fig. 1, and the scenario parameters are provided in Table 3 in the Appendix to this report. The materials and stages were chosen on the basis of their known influence on LIB energy and environmental impacts. Here, the baseline conditions are consistent with the 2018 release of GREET (see Table 3 for description).

GREET is a processed-based LCA model used for the calculation of the energy, water consumption, and air pollutant emissions associated with fuel and material production (Wang 1999; Argonne National Laboratory 2018c). The boundaries for calculation extend from raw material extraction, through processing, refining, and manufacture, to use and end-of-life. GREET has extensive coverage of fuel production including models for petroleum products, natural gas, coal, and more. It combines those fuel models with energy conversion technology models, such as industrial boilers, natural gas combined cycle generators, and many more, to determine the associated combustion emissions. It contains life cycle inventories for dozens of materials, such as steel, aluminum, copper, etc., which include the energy and process emissions associated with each stage of production. Its historical focus has been environmental evaluations of the transportation sector. The model has been used extensively to determine the life cycle energy and environmental effects of vehicle technologies, from well-to-wheels for

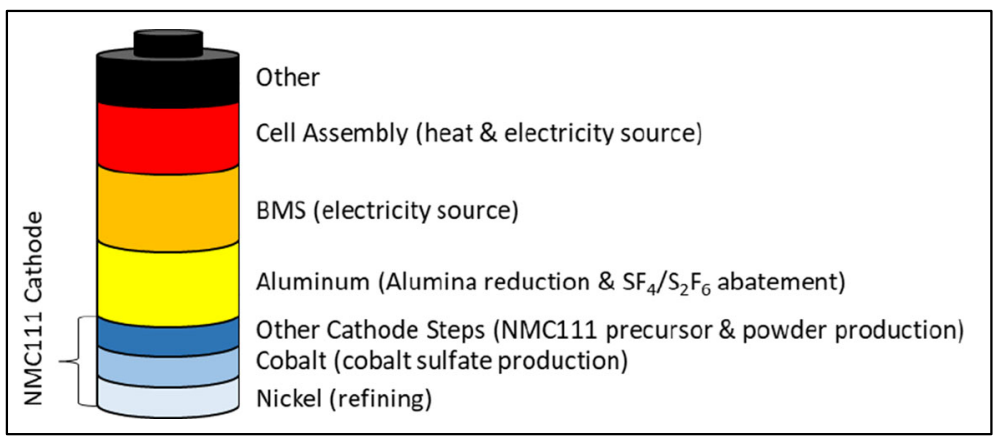

Fig. 1 Battery materials and stages under consideration in the present study 
fuels and from mine to disposal for materials. For its material LCA methodology, it uses a recycled content methodology, meaning that it has separate models of virgin and recycled materials and evaluates a product based on its content of each material type, it does not provide a recycling credit to the product at its end of its life.

The GREET model (Argonne National Laboratory 2018c) currently uses a US-centric material and production supply chain for NMC111, so this was modified to account for the globally regional variability of production for nickel, aluminum, cobalt sulfate, NMC111, battery cell assembly, and the battery management system (BMS). This was done by accessing the GREET processes for each of the noted materials or products and modifying the underlying calculations to utilize different electricity grid profiles, process emissions assumptions, and energy source profiles, depending upon the process. The following sections describe the conditions considered along with the impetus for that consideration.

For a $27-\mathrm{kWh}$ battery produced using conditions from the default GREET model parameters for the NMC111 chemistry: Figure 2 shows the total life cycle energy per kWh, Figure 3 shows the life cycle GHG emissions, and Table 1 gives the material composition. These indicate that nickel, cobalt, and aluminum materials along with NMC111 powder production, BMS production, and cell assembly are all important considerations when evaluating the regional ramifications of automotive NMC111 LIB production. Figure 4 depicts the $\mathrm{SO}_{\mathrm{x}}$ emissions associated with the same production conditions, thus highlighting that one must consider multiple environmental categories to evaluate the performance of battery production. Clearly, some processes can have extremely influential effects on specific emissions while not belying that effect based on energy alone. The nickel-related emissions in this scenario are high because of emissions associated with nickel refining from sulfide ores. Note that the "Other" category in Fig. 2 and elsewhere consists of all materials from Table 1 aside from active cathode, wrought aluminum, and BMS. Within that category, the graphite comprises the plurality of the greenhouse gas (GHG) burden (47\% of Other), while copper (22\%) and the electrolyte $\mathrm{LiPF}_{6}(12 \%)$ are also important contributors. Graphite production has high energy

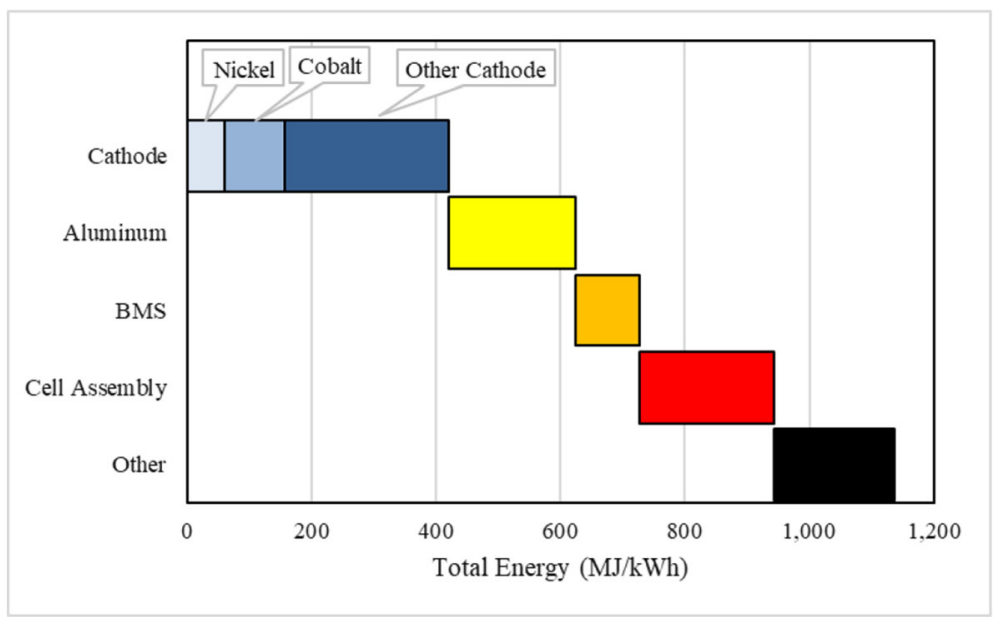

Fig. 2 Total life-cycle energy associated with the production of NMC111 LIB using the baseline GREET2018 conditions 


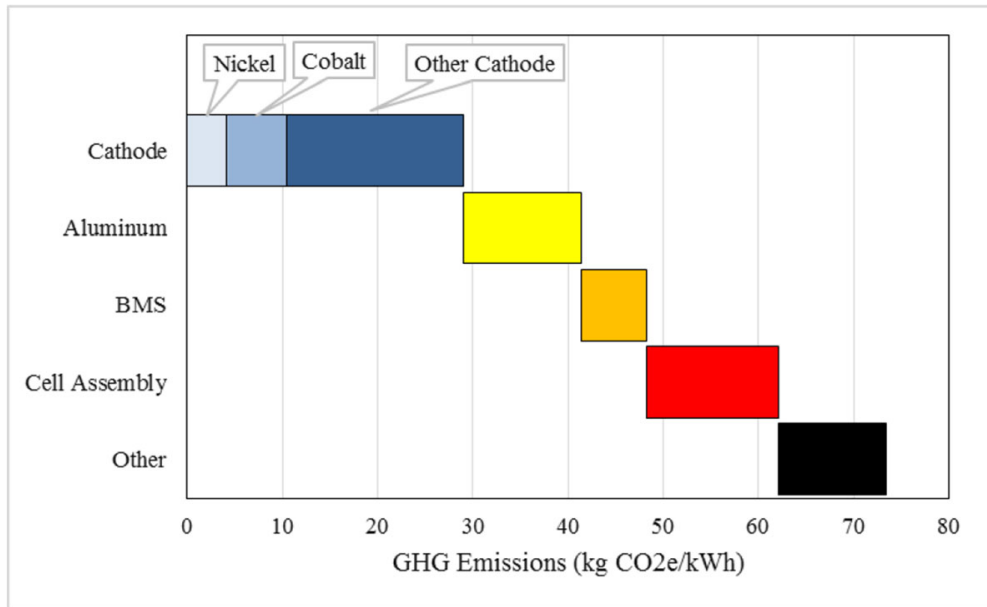

Fig. 3 Total life cycle GHG emissions associated with the production of NMC111 LIB using the baseline GREET2018 conditions

requirements, but not as high as cell assembly or BMS/aluminum/NMC111 powder production, so we do not examine its potential variation.

\subsection{Nickel}

Nickel is used in the cathode material for NMC111, typically sourced as nickel sulfate, which itself is produced from refined nickel. Nickel production is an energy-intensive process. It is composed of several stages that can be roughly classified as mining, beneficiation, primary extraction, and refining. These are the stage definitions within GREET, but the true nickel production process contains many stages within each of the broader classifications provided above. GREET uses these broad classifications to describe the energy and material requirements into and emissions out of each stage. GREET can then determine the total energy and

Table 1 NMC111 LIB (27 kWh) material composition (Argonne National Laboratory 2018b)

\begin{tabular}{ll}
\hline Material & Mass (kg per battery) \\
\hline Active material & 47.49 \\
Graphite/carbon & 29.71 \\
Binder & 4.06 \\
Copper & 22.14 \\
Wrought aluminum & 45.01 \\
Electrolyte: LiPF 6 & 3.04 \\
Ethylene carbonate & 8.50 \\
Dimethyl carbonate & 8.50 \\
Polypropylene & 2.08 \\
Polyethylene & 0.68 \\
Polyethylene terephthalate & 0.39 \\
Steel & 1.17 \\
Thermal insulation & 0.92 \\
Glycol & 8.12 \\
Electronic parts (BMS) & 6.90 \\
\hline
\end{tabular}




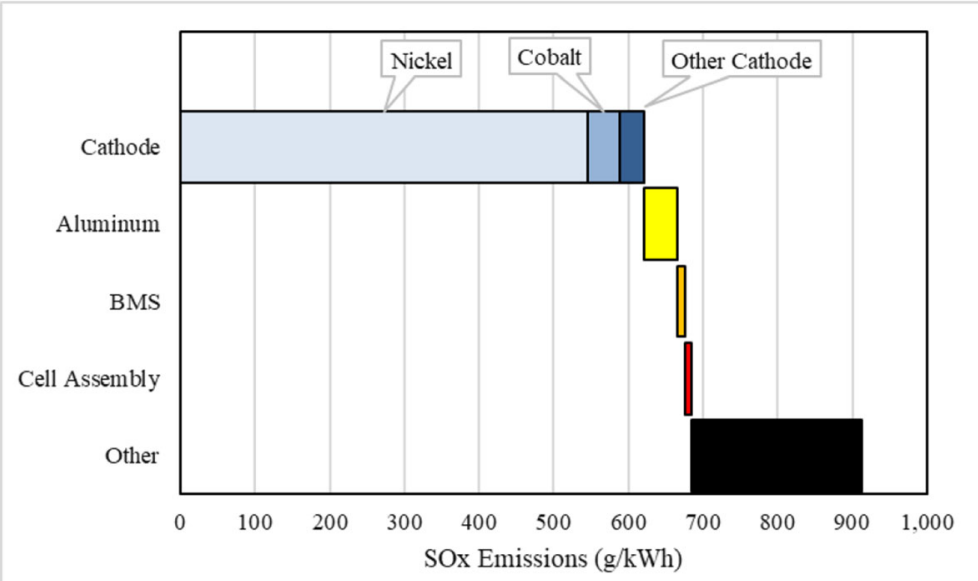

Fig. 4 Life cycle $\mathrm{SO}_{\mathrm{x}}$ emissions associated with the production of NMC111 LIB using the baseline GREET2018 conditions

material inputs of nickel production, and return the total pollutant emissions generated and water consumed.

Nickel is derived from either sulfide or laterite ores (Mudd 2010). Sulfide ores present pollutant challenges because they can form sulfur dioxide, a precursor to acid rain. As such, most nickel production pathways that use sulfide ores capture the sulfur dioxide emissions to produce sulfuric acid, thereby reducing the potential for sulfur dioxide release to the atmosphere and acid rain pollution. Practices worldwide vary in their sulfur capture approaches. Nickel refining is the stage of production most likely to release sulfur dioxide. It is the most energy-intensive stage in the production process because of the high temperatures required. These energy demands are met by natural gas in most production facilities (approximately $66 \%$ ), while coal, diesel, and electricity comprise $12 \%, 11 \%$, and $11 \%$, respectively, of production energy in refining (Benavides et al. 2015).

In this study, the refining process was varied from the GREET default, which considers a US import-weighted average (which can be used as a proxy for global nickel refining) profile for electricity production and sulfur dioxide emissions. The modified version considered nickel refining in four study areas: worldwide, Canada, Russia, and China. The GREET2018 default was used as the baseline. We examined Canada because that country's refining practices are highly regulated and the sulfur there is converted to sulfuric acid. Russia was considered on the basis of its particularly high sulfur dioxide release profiles for nickel refining. We examined China due to its global market presence and assumed that it captures sulfur for sulfuric acid. Worldwide, the largest class I nickel refining regions are China, Russia, and Canada by production volume. Russia and Canada together represent $35 \%$ of the market and comprise a significant share of the US market. China represents $22 \%$ of the global market share but is not highly represented in the US. Canada and Russia represent important boundary scenarios (U.S. Geological Survey and McRae 2018).

We varied both the electricity profile assumed for the refining stage of nickel production and the sulfur dioxide emissions for that stage. Table 4 presents the assumed electricity profiles. Table 5 presents the sulfur dioxide emissions associated with the refining stage for the three profiles, based on Benavides et al. (2015). 


\subsection{Aluminum}

An NMC111 automotive battery is nearly $24 \%$ aluminum by weight; GREET assumes that this aluminum is in wrought form (as opposed to cast). The aluminum is largely used in the packaging of the battery, the cathode current collector, and the thermal management system. Aluminum production is highly energy intensive, especially in its high electricity consumption for the reduction of alumina. This large consumption of electricity represents both a challenge and an opportunity from an energy and environmental perspective. Reducing required energy inputs is always beneficial for a material's life cycle environmental performance (assuming the same energy source is used). However, since electricity is a flexible energy carrier that can be generated from multiple sources, the energy and environmental profile of aluminum produced using electricity sourced from different electrical grids can vary significantly (Colett et al. 2015; McMillan and Keoleian 2009). For example, aluminum produced from coal-based electricity is associated with more $\mathrm{CO}_{2}$ emissions than aluminum produced from lowemissions electricity such as hydroelectric, solar, and wind power. In addition to the electricity source, alumina reduction can also be associated with the production of $\mathrm{CF}_{4}$ and $\mathrm{C}_{2} \mathrm{~F}_{6}$, which are both potent greenhouse gases (Dai et al. 2015). The released amount of these two gasses assumed within the GREET model is based on industry reporting; however, it is feasible that these gases can be abated.

In this study, we considered aluminum obtained from six different sources and scenarios where $\mathrm{CF}_{4}$ and $\mathrm{C}_{2} \mathrm{~F}_{6}$ were either released or abated. The electricity profiles considered are shown in Table 3 and were selected based on their regional variations. The baseline for GREET uses electricity grid profiles for aluminum smelters in North America. North American and European aluminum production consumes significant amounts of hydroelectric power, resulting in low GHG emissions. We also considered aluminum production in China, Japan, and South Korea using the electricity grid profiles noted in Table 4, and for electrical grids powered only by hydroelectric power or renewable electricity (solar and wind). China is the leading producer of aluminum, with $54 \%$ of global primary aluminum production in 2016; Canada was third with $5.5 \%$, European countries combined to represent $6.3 \%$, and the US produced $1.4 \%$. Neither Japan nor Korea are major global aluminum producers. Data for European, Chinese, and Korean aluminum electricity profiles were derived from World Aluminum (World Aluminum 2018), while Japanese data were derived from the Japanese Aluminum Association (Japan Aluminum Association 2014), and the U.S. profile is based on GREET (Argonne National Laboratory 2018c). For Korean aluminum, we used the world production average from World Aluminum, because data for Korea's production and import profiles were not available.

\subsection{Cobalt sulfate}

Cobalt sulfate is a precursor in the production of the NMC111 cathode material. Cobalt is largely mined in the Democratic Republic of Congo, then concentrated and converted into crude $\mathrm{Co}(\mathrm{OH})_{2}$, and subsequently converted into various cobalt-containing chemicals, such as $\mathrm{CoSO}_{4}$. The final conversion process, into $\mathrm{CoSO}_{4}$, is very energy intensive, and largely occurs in China. GREEET2018 assumes that this conversion occurs in China and is powered by electricity from the Chinese national grid (2018). However, the actual electricity profile for $\mathrm{CoSO}_{4}$ conversion may differ substantially from that of the national grid. Additionally, other countries may become notable $\mathrm{CoSO}_{4}$ producers to guard against supply disruption as they 
ramp up LIB production. Therefore, we considered the production of $\mathrm{CoSO}_{4}$ in the US and China, and electrical grids entirely from coal (a "worst-case" $\mathrm{CO}_{2}$ scenario), from solar or wind power (a "best-case" $\mathrm{CO}_{2}$ scenario), or from hydroelectric power. Solar and wind power do not have water consumption impacts, but the hydroelectric power scenario does, through evaporation from the water body surface. These conditions are presented in Table 3, and the associated electrical grid profiles are in Table 4. Since the cobalt chemicals market is so dominated by China at present, we only examined its possible production in the US as a case study.

\subsection{NMC111}

This study examined NMC111 as the active cathode material for the LIBs. While much of the energy and pollutant emissions associated with NMC111 is contributed by the manufacture of its constituent material, the NMC111 powder synthesis process is also an important contributor. NMC111 production consists of several stages of mixing and calcination that are all powered by electricity. These stages are combined in GREET to identify a single quantity of electricity that is consumed per mass of NMC111 production. In GREEET2018, NMC111 is assumed to be produced in the U.S. However, much of the world's NMC, in its various chemical combinations $(111,532,622,811)$, is produced in China and Korea. Japan and Europe are also important current and future production markets for NMC111. Therefore, we modeled NMC111 production in each of these countries, and also modeled production using electrical grids composed of only coal-powered plants, only solar- and wind-powered plants, and only hydroelectric power plants. Table 4 lists the electrical power assumptions.

\subsection{Cell assembly}

Cell assembly is a major energy consumer in the battery manufacturing process. It consists of electrode production, cell stacking, current collector welding, cell encasement, electrolyte filling, and cell closure (Dai et al. 2017). Each of these steps occurs within a dry room to prevent the electrolyte salt, LiPF6, from reacting with water (Ahmed et al. 2016a). The moisture content of the air cannot exceed 100 ppmv, which requires substantial heating, cooling (for condensation), and circulation of the air. Researchers have identified the dry room as a major contributor to the total LIB manufacturing energy requirement in previous LIB LCA studies (Dunn et al. 2015; Ellingsen et al. 2014; Dai et al. 2017). Wood III et al. indicated that energy use in LIB manufacturing is dominated by cathode drying and N-methylpyrrolidone (NMP) recovery, in addition to cell wetting and formation (Wood et al. 2015). Ahmed et al. determined that cathode drying, NMP recovery, and dry room operation are major drivers of LIB manufacturing energy demand (Ahmed et al. 2016a, 2016b). Dai et al. compiled a life cycle inventory for LIB manufacturing based on real-world data to further understand the influence of each manufacturing stage on total energy inputs to the battery (Dai et al. 2017). They confirmed that these dry room activities associated with cell production, along with cathode drying, are important contributors to the total energy consumed in the production of LIB.

In this study, we used the GREET2018 baseline assumptions for total energy consumption in the cell assembly process. In its base configuration, that process consumes $82.4 \%$ natural gas (for steam generation) and $17.6 \%$ electricity. The basis for the electricity generation of this process in GREEET2018 is the US (i.e., the cell is manufactured in the US). We considered variations in the electrical grid for several different geographic regions (US, China, Japan, Korea, and Europe) and specific grid energy sources (coal, solar and wind, and hydroelectric 
power). In addition, since electricity can be used in place of natural gas for heat in this process, we also considered a scenario where all energy for this process was from electricity, to observe the total effects on energy consumption and emissions. Those conditions are summarized in Table 3, and the associated electrical grid profiles are in Table 4.

\subsection{Battery management system}

In GREEET2018, the BMS includes other electronic parts which are modeled as a circuit board and semiconductor (Argonne National Laboratory 2018a). In GREET2018's baseline conditions, the BMS production occurs in the US and constitutes $9.1 \%$ of the LIB's life cycle energy consumption. Here, we examined the effects of BMS production in the US, China, Japan, Korea, and Europe, and scenarios when electricity was sourced from coal only, solar and wind only, or hydroelectric power only, as detailed in Table 3.

\section{Results}

Our LCA for NMC111 LIB used many different scenarios and considered multiple supply chains that span several different global regions. Figure 5 presents the life cycle GHG emissions associated with the production of one $27-\mathrm{kWh}$ NMC111 LIB on a per-kWh basis, while Figs. 6 and 7 show the life cycle $\mathrm{SO}_{\mathrm{x}}$ emissions and water consumption for the same. The four scenarios depicted are, from left to right, a best case, a GREET2018 baseline, a currently dominant supply chain, and a worst case. Table 3 (boundary examination scenario) shows the parameters for these scenarios. We observed that the best-case scenario produced substantially less GHG and $\mathrm{SO}_{\mathrm{x}}$ emissions than the worst-case scenario. The best case: (1) used Canadian refined nickel; (2) did not release $\mathrm{CF}_{4}$ or $\mathrm{C}_{2} \mathrm{~F}_{6}$ during aluminum production, which was produced via hydroelectric power; (3) used renewable electricity during cell production; and (4) used renewable electricity for all other noted pathways. The worst case: (1) used Russian-based nickel production; (2) released $\mathrm{CF}_{4}$ or $\mathrm{C}_{2} \mathrm{~F}_{6}$ for aluminum produced in China; (3) used coal-based electricity during cell production; and (4) sourced electricity for the other noted pathways from coal.

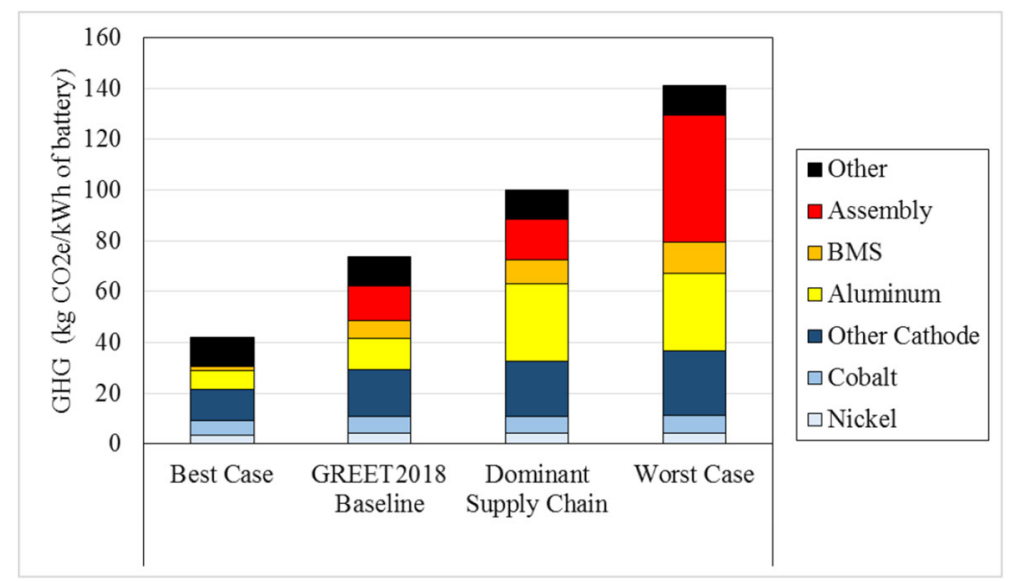

Fig. 5 GHG emissions associated with NMC111 LIB production via different supply chains 


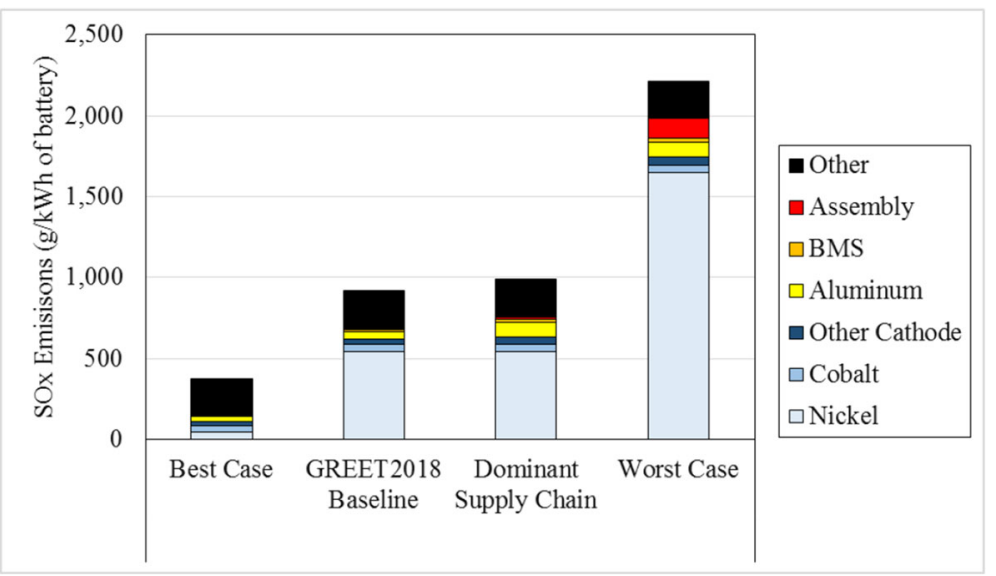

Fig. $6 \mathrm{SO}_{\mathrm{x}}$ emissions associated with $\mathrm{NMC1} 11 \mathrm{LIB}$ production via different supply chains

We also observed that the GREET2018 baseline, which is largely US-centric, produced significantly less GHG emissions, and nearly the same quantity of $\mathrm{SO}_{\mathrm{x}}$ emissions as the currently dominant supply chain, which is largely based on Chinese production; however, that GREET2018 baseline consumed significantly more water due to GREET's default alumina reduction assumptions about hydroelectric power ( $81.1 \%$ of the electricity mix). Note that the "Other" category is composed of additional battery components not parametrically evaluated here and uses standard GREET assumptions for its LCA. "Other Cathode" consists of upstream materials, including manganese sulfate (MnSO4), sodium hydroxide $(\mathrm{NaOH})$, and ammonium hydroxide $(\mathrm{NH} 4 \mathrm{OH})$, and processing energy for $\mathrm{NMC111}$ precursor and powder production.

\subsection{Country-specific supply chains}

We evaluated the production of NMC111 batteries considering the supply chains of the US, China, South Korea, Japan, and Europe. Regionalized (country/region-specific) conditions were used for the production parameters. However, some production parameters were not

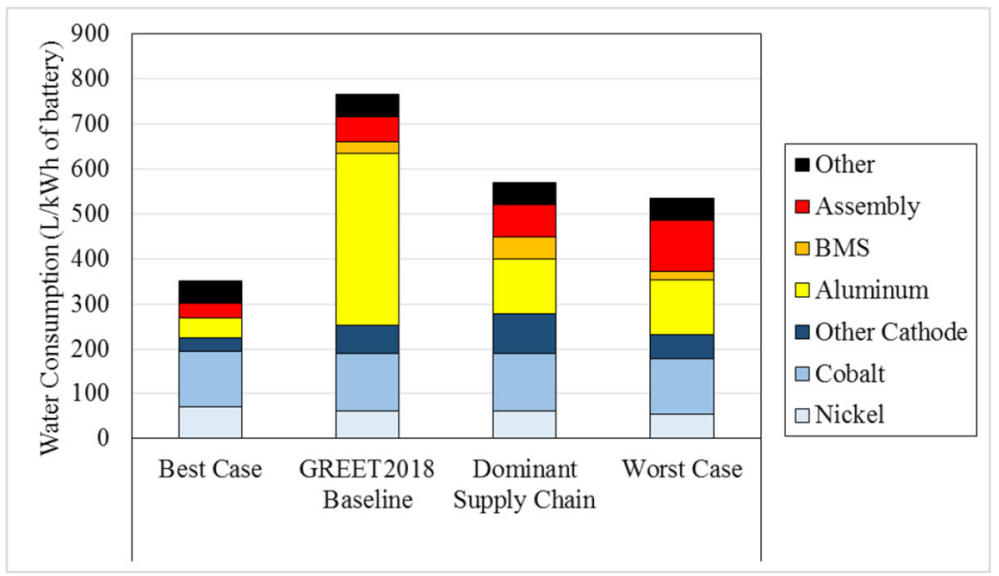

Fig. 7 Water consumption associated with NMC111 LIB production via different supply chains 
regionally specific in this analysis. In particular, $\mathrm{CoSO}_{4}$ production occurred in China due to Chinese market dominance in this material's production. Table 3 (individual country scenario) details the parameters for each scenario.

Figure 8 shows GHG emission levels associated with production of NMC111 LIB in the noted countries, while Fig. 9 shows water consumption, Fig. $10 \mathrm{NO}_{\mathrm{x}}$ emissions, and Fig. 11 $\mathrm{SO}_{\mathrm{x}}$ emissions. Production in the US and Europe tended to have the lowest GHG emissions, mainly due to the lower GHG intensity of their electrical grids. This was most pronounced in the aluminum, NMC (other cathode), and assembly stages. On the other hand, we observed that the US and European reliance on aluminum whose electricity source was hydroelectric power had a dramatic impact on the LIB's water consumption when produced in those regions versus others. Next, we observed that the Japanese electricity profile suggested it could produce LIB with significantly more $\mathrm{NO}_{\mathrm{x}}$ emissions than the other production regions due to its comparative reliance on petroleum for electricity generation (13.4\%). Finally, we observed that $\mathrm{SO}_{\mathrm{x}}$ emissions in China, Japan, and South Korea were much lower than in their US and European counterparts, which derived from assumptions regarding the nickel supply chain. For the US and Europe, we assumed the GREET default, which contains Russian nickel, which is known for high $\mathrm{SO}_{\mathrm{x}}$ emissions. Chinese nickel was assumed for the other regions and did not have the same assumptions regarding $\mathrm{SO}_{\mathrm{x}}$.

\subsection{Regional nickel production}

Nickel production was examined due to its potential impacts on overall $\mathrm{SO}_{\mathrm{x}}$ emissions. These emissions are the product of ore type, namely sulfide ores as opposed to laterite ores, and nickel refining practices (i.e., whether $\mathrm{SO}_{2}$ is captured and turned into sulfuric acid). Figure 12 shows the energy, air emissions, and water consumption associated with NMC111 LIB production with nickel sourced from the baseline (GREET), Canada, Russia, and China. These results are presented as a percentage relative to the GREET baseline condition. We observed that most categories of interest were roughly equal to the baseline battery condition, yet Russian-sourced nickel increased the battery's total $\mathrm{SO}_{\mathrm{x}}$ emissions by $121 \%$ (914 vs. $2017 \mathrm{~g} \mathrm{SO}_{\mathrm{x}} / \mathrm{kWh}$ of battery). This result is striking because there are many industry solutions worldwide that facilitate $\mathrm{SO}_{\mathrm{x}}$ reduction, and, here we saw the most dramatic difference in regional production practices for any

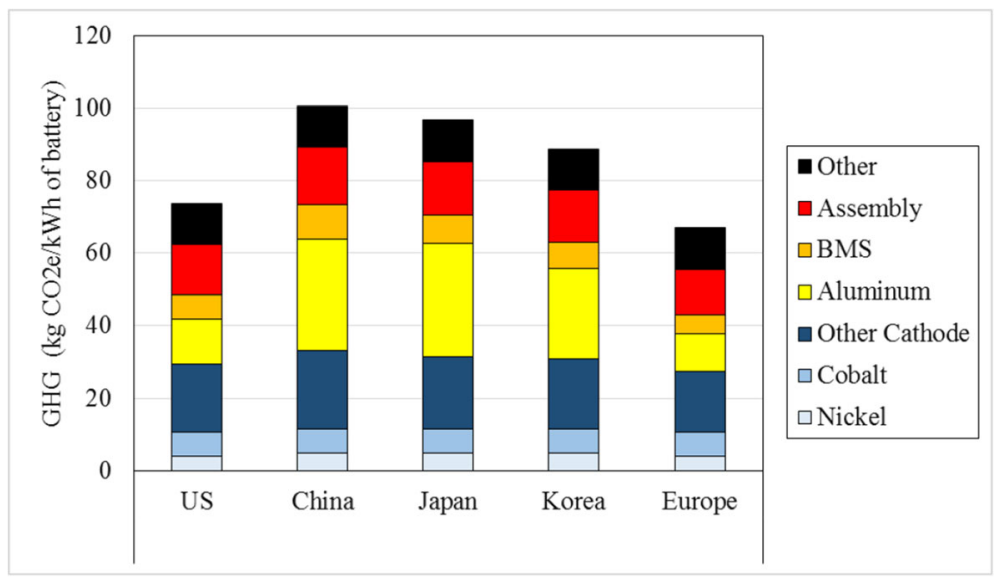

Fig. 8 GHG emissions associated with NMC111 LIB production in five countries 


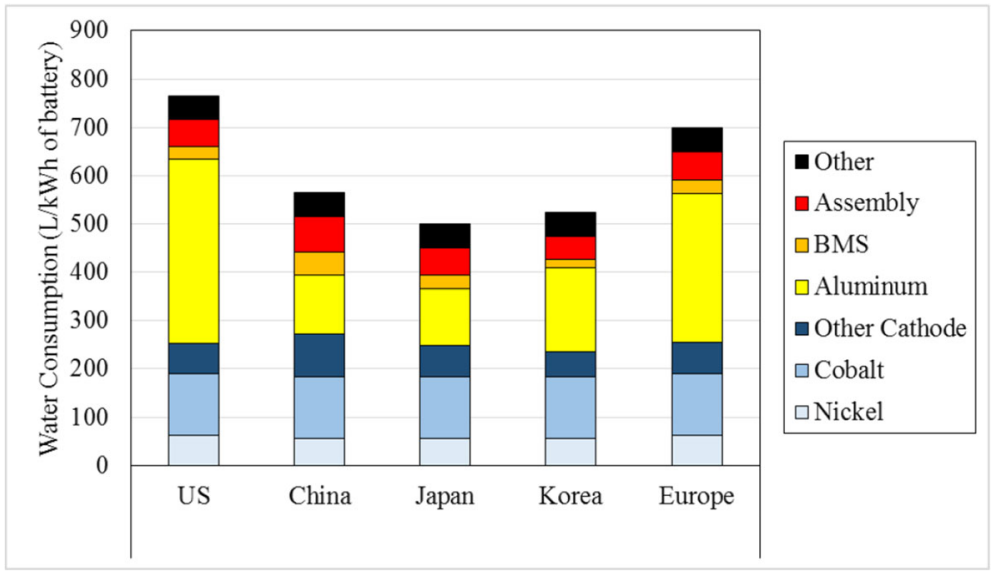

Fig. 9 Water consumption associated with NMC111 LIB production in five countries

individual aspect of LIB production. Further, if we zoom in to just the effects of nickel production (Fig. 13), Russian nickel had $300 \%$ the $\mathrm{SO}_{\mathrm{x}}$ emissions as the baseline, while Canadian and Chinese nickel had $8 \%$ of the baseline. Note that the baseline condition was the US importweighted nickel profile, which contains about one-third Russian nickel (Benavides et al. 2015).

\subsection{Regional aluminum production}

Aluminum smelting is energy intensive and has the potential to release $\mathrm{CF}_{4}$ and $\mathrm{C}_{2} \mathrm{~F}_{6}$, which are potent GHGs. We considered the influence of smelting electricity and $\mathrm{CF}_{4}$ and $\mathrm{C}_{2} \mathrm{~F}_{6}$ abatement on energy, emissions, and water consumption for the conditions outlined in Table 3 (alumina reduction, $\mathrm{CF}_{4} / \mathrm{C}_{2} \mathrm{~F}_{6}$ scenarios). The results of the $\mathrm{CF}_{4} / \mathrm{C}_{2} \mathrm{~F}_{6}$ analysis showed a $1.3 \%$ reduction in the GHG emissions for NMC111 LIB. For aluminum alone, this corresponded with an $8 \%$ reduction in GHG emissions per $\mathrm{kg}$ of aluminum. The grid-specific results are presented in Fig. 14, from which we observe that aluminum production in most regions outside of the baseline (North American aluminum conditions) indicated a significant reduction in

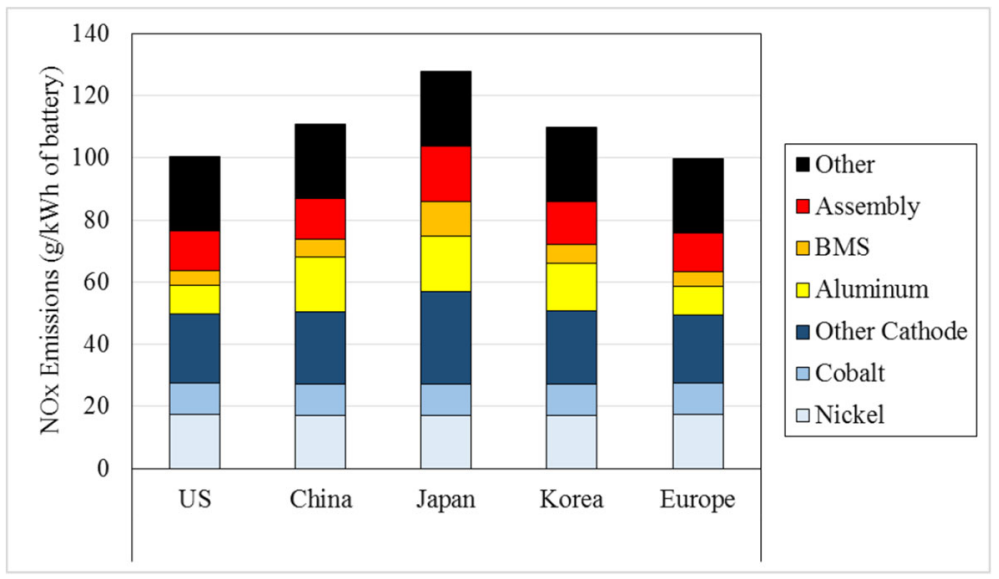

Fig. $10 \mathrm{NO}_{\mathrm{x}}$ emissions associated with NMC111 LIB production in five countries 


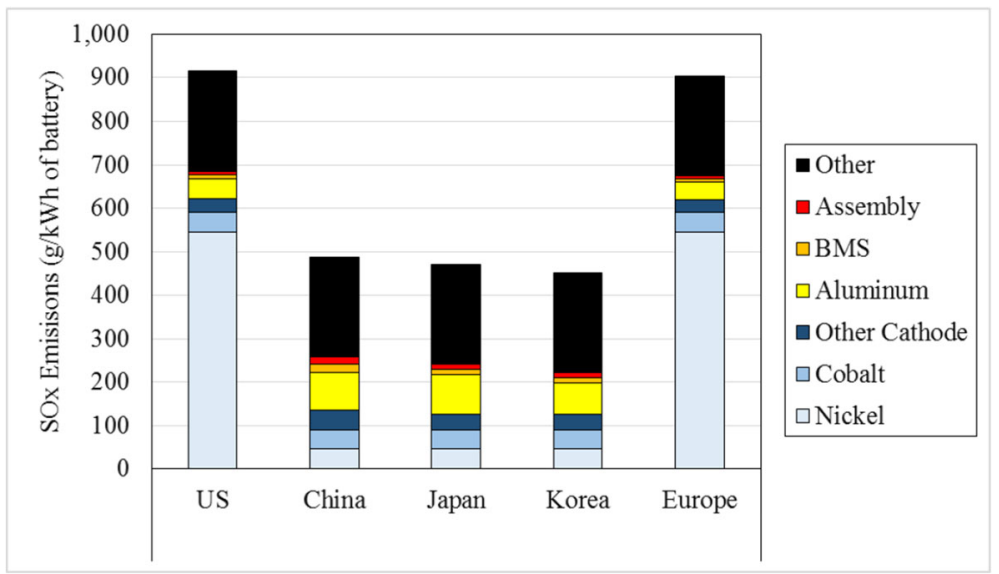

Fig. $11 \mathrm{SO}_{\mathrm{x}}$ emissions associated with $\mathrm{NMC1} 11 \mathrm{LIB}$ production in five countries

water consumption. The aluminum profile for the US is heavily influenced by hydroelectric power, while, outside of Europe, which is also hydroelectric intensive (61.7\% of grid mix), aluminum-production electricity profiles are less hydroelectric reliant. We used aluminumspecific electric grid profiles as specified in Table 4.

To help orient the reader, we further explain Fig. 14 since it is similar to several of the figures later in the text. In these figures, data may appear to be presented as a histogram, but this is not the case. Each bar represents our GREET-based estimate of that material's impact on the burden category noted if produced using the grid mix noted in comparison to the baseline. So, each bar represents a difference from the baseline considering regional production. This provides insight into that material's production variance but is limited by the scope of this study. GREET does not have inventory variability or uncertainty for materials, this analysis explores that variability for the specific processes and grid mixes noted and presents them throughout the results.

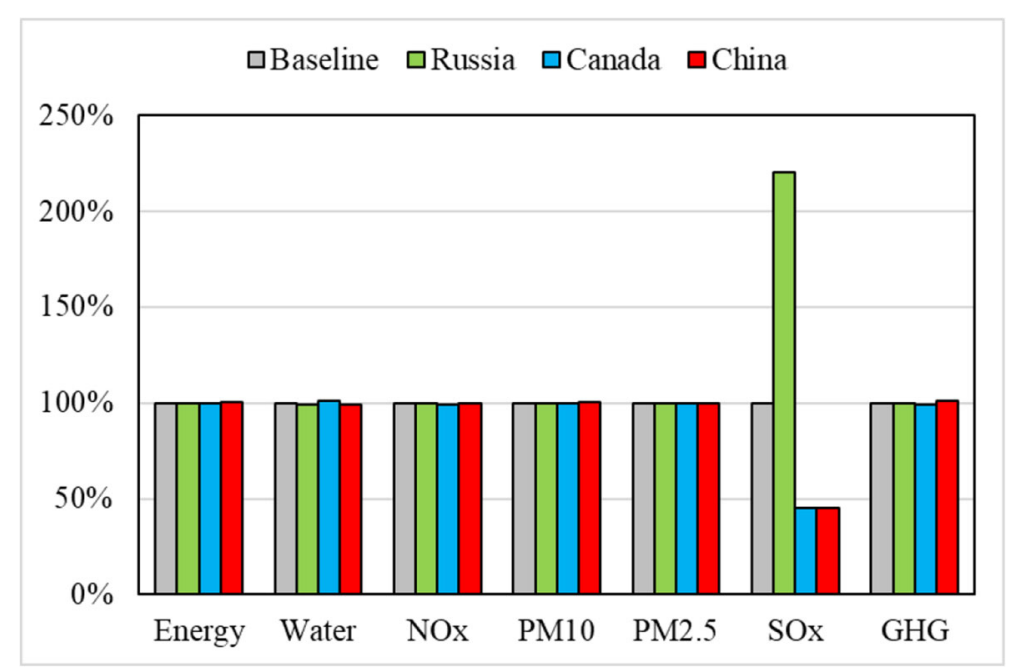

Fig. 12 Energy consumption, emissions, and water consumption associated with production of NMC111 LIB considering nickel produced under baseline conditions and in Russia, Canada, and China 


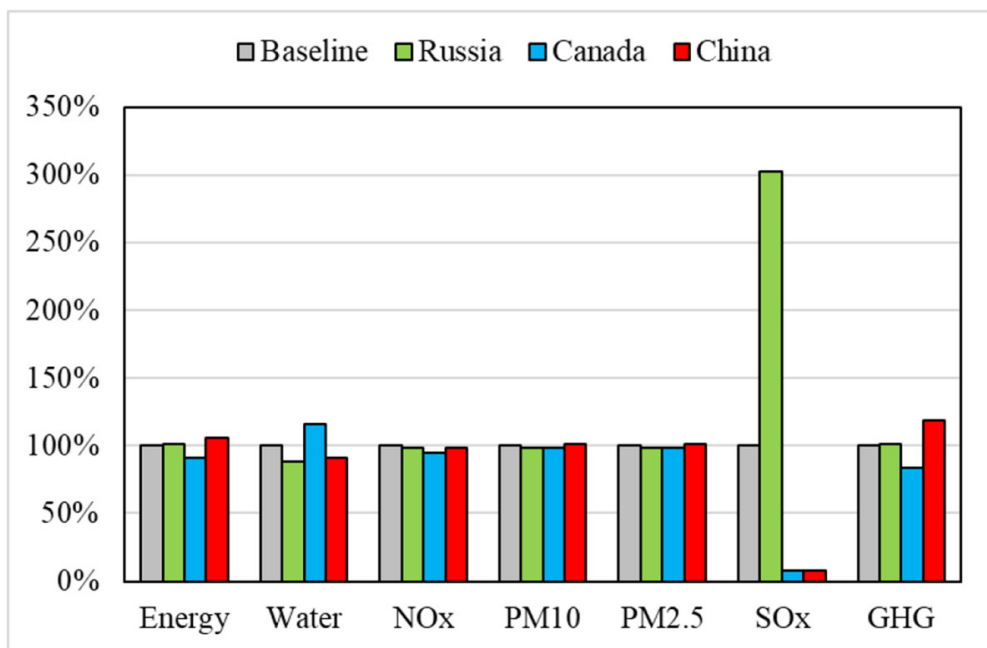

Fig. 13 Energy consumption, emissions, and water consumption associated with production of nickel produced under baseline conditions and in Russia, Canada, and China

\subsection{Regional cobalt sulfate production}

The variation in cobalt sulfate production considered for this LCA used the scenarios in Table 3 ( $\mathrm{CoSO}_{4}$ scenario): electricity profiles for the baseline condition (US), renewable electricity (solar and wind power), hydroelectric power, and coal-based electricity. The influence of cobalt sulfate production on the LIB was relatively small in each category examined. No categorical difference was greater than $2.5 \%$ for the LIB. Isolating cobalt production showed that water consumption increased by $12 \%$ on a per-kg $\mathrm{CoSO}_{4}$ basis for a hydroelectric power grid compared with the baseline, and GHG emissions decreased by $10 \%$ for the renewable-based

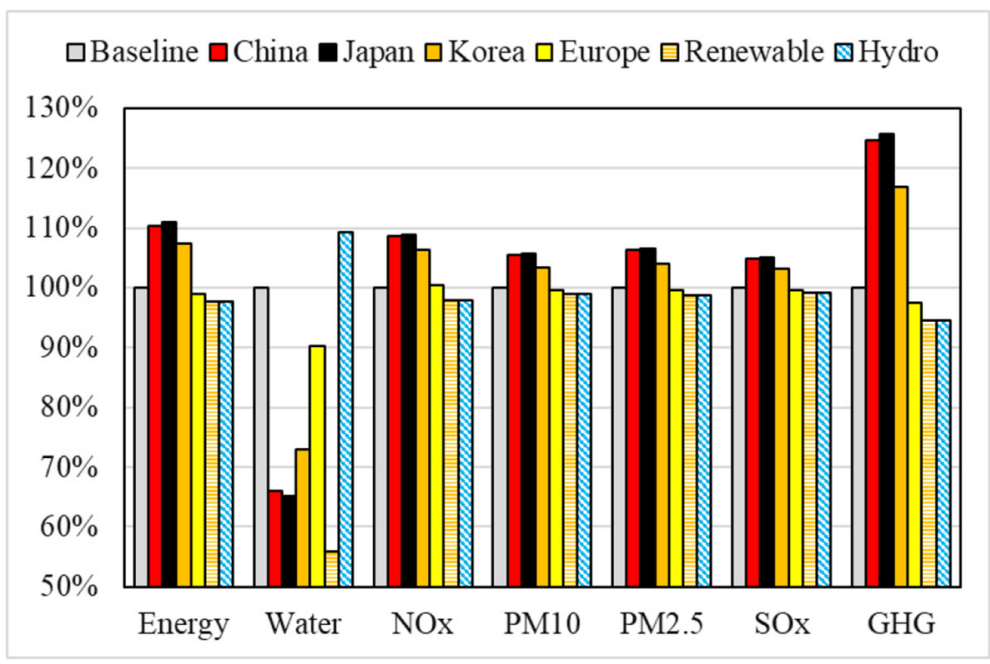

Fig. 14 Energy, emissions, and water consumption associated with the production of NMC111 LIB considering production of aluminum in a baseline condition, in four geographic regions, and with two different electrical energy sources 
and hydroelectric grid profiles and increased by $10 \%$ for a coal-based electricity grid. The effect of $\mathrm{CoSO}_{4}$ production on the LIB was small compared with the rest of the battery constituents.

\subsection{Regional NMC111 production}

For NMC111, we varied only the production location (electricity profile), as shown in Table 3 (NMC scenario). The use of hydroelectric power had an outsized effect on water consumption in NMC111 production compared with the baseline scenario. It represented a nearly $300 \%$ increase in water consumption for NMC production alone and a $25 \%$ increase for the total battery. These trends were also true for the cell assembly and BMS scenarios, but their magnitudes were different. We can see these isolated effects of NMC111 cathode powder production in Fig. 15, and its effects on the entire battery in Fig. 16.

\subsection{Cell assembly}

The analysis for cell production was the same as for NMC cathode powder production in terms of electrical grids considered. However, in addition to the baseline energy source mix $(82.4 \%$ natural gas, $17.6 \%$ electricity), we also considered an energy source of $100 \%$ electricity. The total battery effects considered different electrical grid profiles, as shown in Table 3 (cell assembly location scenario and cell assembly location and fuel mix scenario). Results that only vary the cell location from the baseline are shown in Fig. 17, while those varying the cell location with $100 \%$ electricity are shown in Fig. 18. We observed that the effects of the grid changes were as anticipated, where those characterized by more fossil fuel produced more emissions than the baseline, though not in strictly uniform ways due to the varying emissions intensities of each grid. Further, we observed that the effect of using $100 \%$ electricity for cell production made the effects observed in Fig. 17 more pronounced (i.e., energy, emissions, or water consumption were increased or decreased more than in the base energy condition).

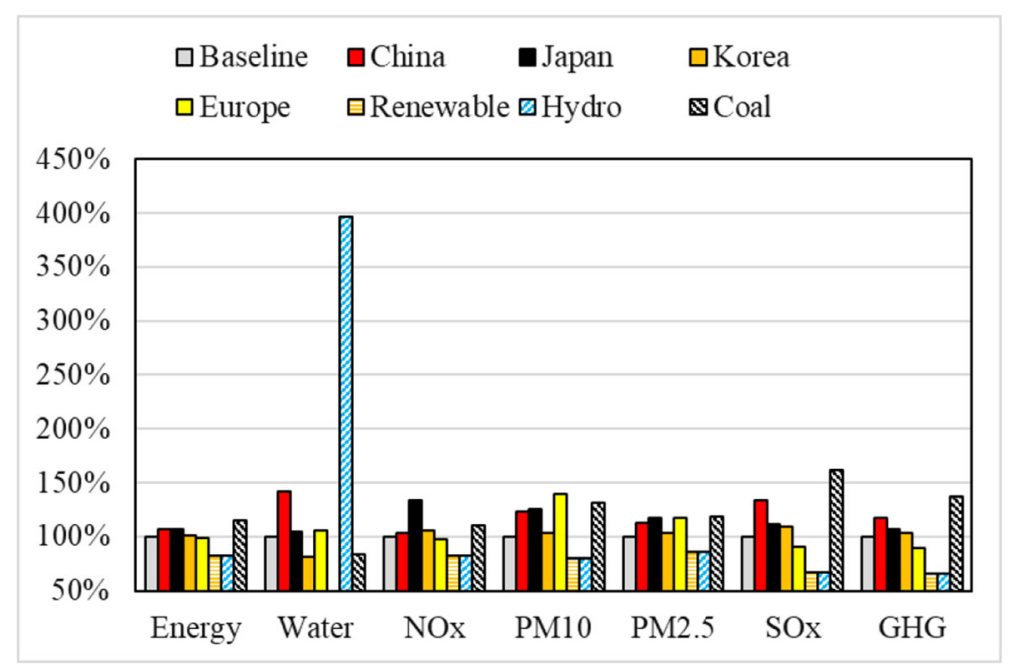

Fig. 15 Energy, emissions and water consumption associated with the production of NMC111 cathode powder under baseline conditions, in four geographic regions, and with three different electrical energy sources 


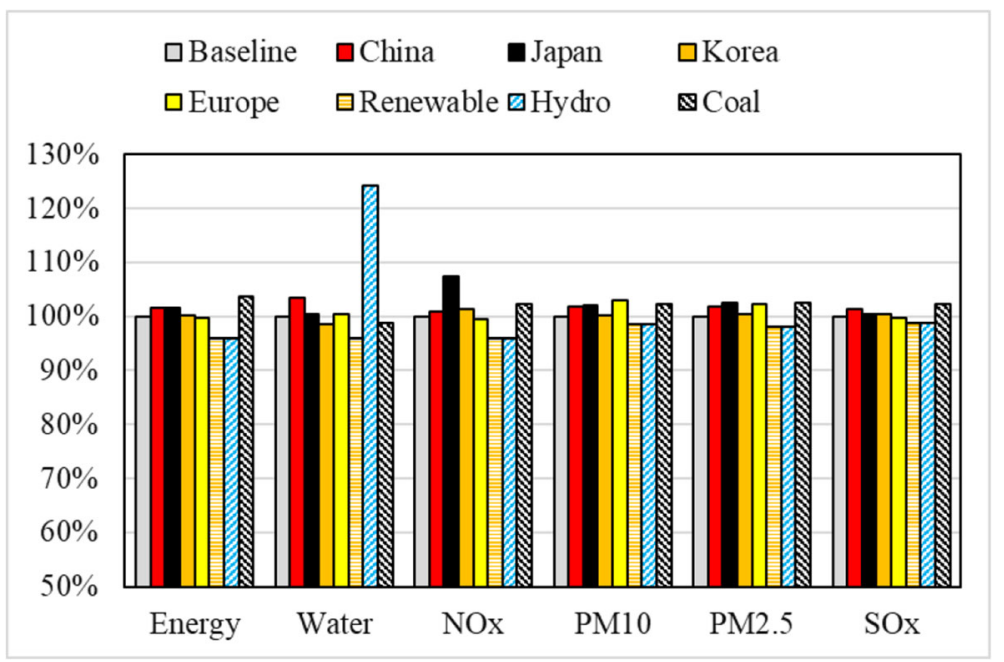

Fig. 16 Energy, emissions, and water consumption associated with the production of NMC111 LIB considering production of NMC111 cathode powder under baseline conditions, in four geographic regions, and with three different electrical energy sources

\subsection{Battery management system}

In Fig. 19, we present results of the BMS scenario analysis on the total battery considering different geographic regions and different electricity sources. These results mirrored closely those of NMC111 cathode powder production. As expected, they indicated that using electrical

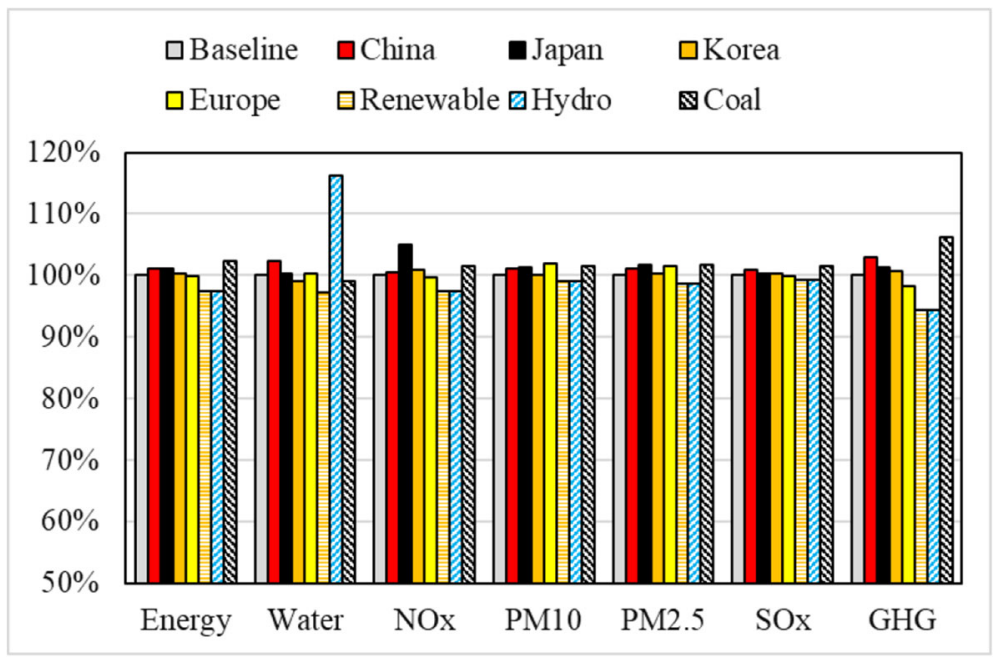

Fig. 17 Energy, emissions, and water consumption associated with the production of NMC111 LIB considering cell production, using $82.4 \%$ natural gas and $17.6 \%$ electricity under baseline conditions, in four geographic regions, and with three different electrical energy sources 


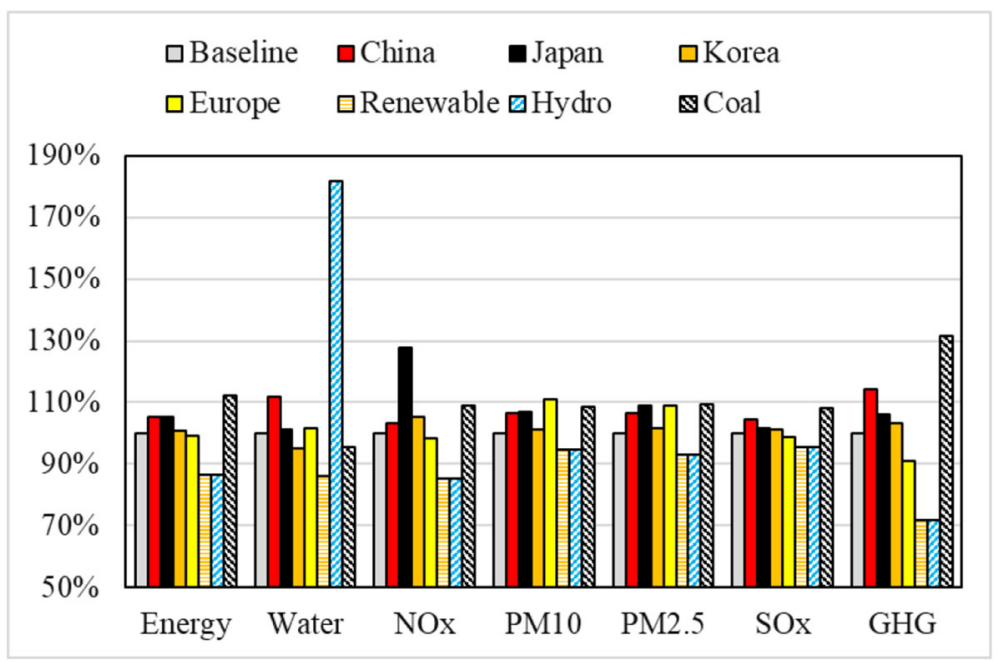

Fig. 18 Energy, emissions, and water consumption associated with the production of NMC111 LIB considering cell production, using $100 \%$ electricity under baseline conditions, in four geographic regions, and with three different electrical energy sources

grids that rely exclusively on hydroelectricity, renewable electricity, or coal electricity yielded the most pronounced results for either increased or decreased performance compared with the baseline condition. All of the regional electrical grids were some combination of fossil fuels (including coal), renewable, and hydroelectric resources. Thus, they all performed somewhere between those boundary conditions.

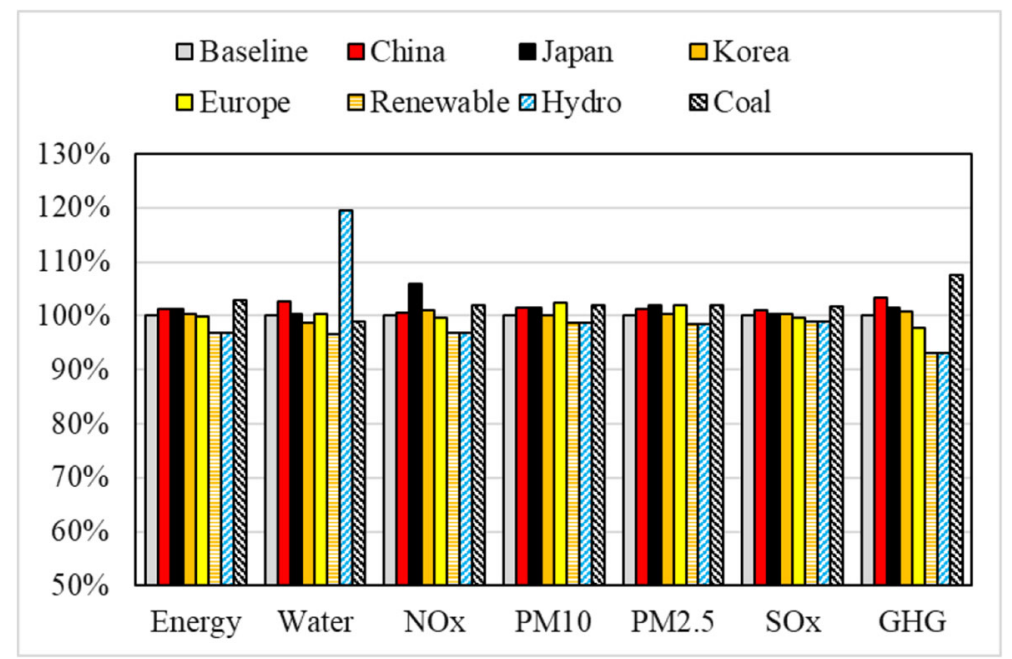

Fig. 19 Energy, emissions, and water consumption associated with the production of NMC111 LIB considering BMS production under baseline conditions, in four geographic regions, and with three different energy sources 


\subsection{Summary}

Table 2 shows the minimum and maximum variation of each parameter compared with the baseline condition. Nickel refining, alumina reduction, and cell assembly were the most impactful stages of production on the total LIB within each energy and environmental category, but their impacts were not always within the same category.

\section{Discussion and conclusions}

We investigated the effect that several production parameters have on the life cycle energy, emissions, and water consumption of NMC111 LIBs for electric vehicles. Results are presented on a per-kWh basis, but the battery examined had a capacity of $27 \mathrm{kWh}$ and it should not be assumed that the per-kWh results can be used to scale for other batteries in a linear fashion. We considered battery component production in several different regions of the world with a focus on the electricity profiles for those locations. We additionally considered production of some components in single-energy-source electrical grids (renewable, hydroelectric, and coal) to observe certain boundary limits.

In this study, we identified the alumina reduction, nickel refining, and cell assembly stages as particularly influential for certain categories of the life cycle inventory. Alumina reduction via the Hall-Héroult process consumes a significant amount of electrical energy. Since aluminum comprised $24 \%$ of the LIB mass studied here, it is not surprising that it played an important role in the total LCA effects. Changes to the electrical grid responsible for reducing alumina can dramatically increase or decrease total energy and emissions, though we note that the effect of limiting $\mathrm{CF}_{4}$ and $\mathrm{C}_{2} \mathrm{~F}_{6}$ did not have a pronounced effect on the overall reduction in battery GHG emissions. Using hydroelectric power for alumina reduction, as is common in North America due to its low cost, had a large effect on the life cycle water consumption of the battery. And, in fact, hydroelectric power dramatically reduced pollutant emissions but substantially increased total water consumption for many of the investigated scenarios. Renewable electricity (from solar and wind sources) facilitated the same emissions reduction while not consuming water in the process.

Nickel is a major constituent of the active cathode material, but its most important contribution to the life-cycle effects was its potential for $\mathrm{SO}_{\mathrm{x}}$ emissions. This is an issue for Russian-produced nickel, but it does not represent an inherent impediment of nickel, in general. While nickel can be obtained from sulfide ores, there are sufficient and effective technological approaches for capturing $\mathrm{SO}_{2}$ emissions and converting them into sulfuric acid, as is done in most other major nickel-producing regions.

Cell assembly accounts for $18 \%$ of the LIB life cycle energy in the baseline scenario. Much of the energy in that baseline scenario is composed of natural gas for steam (82.4\%), while the remainder is electricity. We considered several regional and energy source conditions for electricity, in addition to considering scenarios wherein all energy was sourced from electricity. We found that changes to the assembly grid mix from the baseline (US) condition could increase the battery's GHG emissions by $14 \%$ (China) or reduce it by $9 \%$ (Europe) if all assembly energy was electric. If the electricity was $100 \%$ renewable, the reduction was $29 \%$ from the baseline condition. However, a coal-only electricity grid increased GHG emissions by $31 \%$. 


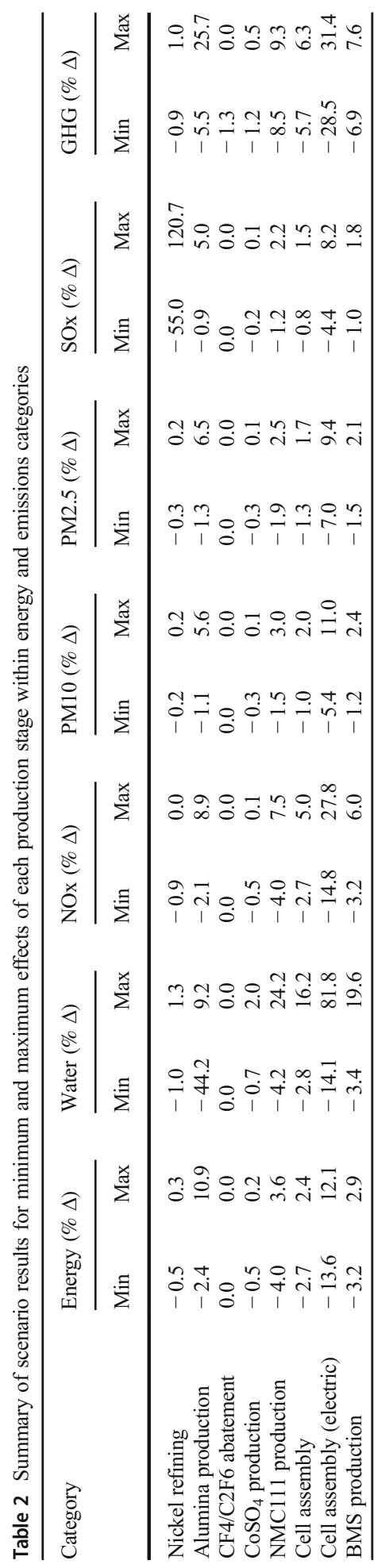


The primary findings from this study indicate that there are important regional effects associated with the total life cycle energy, emissions, and water consumption of LIB NMC111 production. The baseline scenario of the GREET2018 model considers a US-dominant supply chain. Other global supply chains can yield very different results within the life cycle categories evaluated. NMC111 batteries produced in China with a Chinese-dominant supply chain would increase GHG emissions by $36 \%$, yet they would reduce water consumption by $26 \%$. NMC111 batteries produced in Europe with a European-dominant supply chain would reduce both GHG emissions and water consumption by $9 \%$.

Within the current supply chain, we found no avenue that reduced all life cycle categories. If a truly $100 \%$ renewable grid (without hydroelectric power) could be identified and utilized for all process stages, that would have the most profound impact and would serve as the proverbial "silver bullet." However, alumina reduction relies heavily on hydroelectric power or coal power in most parts of the world due to price and stability. The European battery supply chain was the best region-specific supply chain examined, yet even that presented $7 \%$ and $5 \%$ increases in $\mathrm{PM}_{10}$ and $\mathrm{PM}_{2.5}$ emissions, respectively. The most salient recommendation for achieving improved life cycle performance is to utilize electricity grids that have substantial production from renewable resources, aside from hydroelectric, and to migrate cell assembly processes from natural gas to electricity (in those renewable electricity grids).

Near-term trends highlight that many countries and regions are making major investments in their battery production capacities. Lutsey et al. reported that LIBs are currently produced in diffuse plants scattered throughout Asia, America, and Europe, and that a small number of large LIB factories ( $>5 \mathrm{GWh} /$ year production) are expected in China, South Korea, Hungary, Poland, and Sweden (2018). We anticipate that with continued production, more efficient plant design and energy conservation measures manufacturers may be capable of achieving some energy reduction. The trend for energy production worldwide is away from fossil fuels and toward renewable sources, and China has major ongoing efforts toward pollutant reduction. This all indicates that the near-term supply chain for automotive LIB NMC111 production will likely be associated with lessening energy consumption and pollutant emission profiles.

Decision makers and other stakeholders concerned about the energy, water consumption, and air pollutant burdens associated with the LIB in their supply chain can take several steps to reduce those burdens. First, where possible, electricity from renewable sources should be used to the extent possible, since renewable electricity can drastically reduce the pollutant emissions from processes with high electricity usage. Next, they can identify and prioritize material producers and material production locations that abide by strong air quality environmental regulations to factor environmental burdens into their supply chain purchase decisions. Finally, they can use the information presented here to align their supply chain activities with their environmental goals.

Acknowledgements We would like to thank David Howell and Samuel Gillard from the Vehicle Technologies Office of the U.S. Department of Energy's Office of Energy Efficiency and Renewable Energy for their support.

Funding information This study was supported by the Vehicle Technologies Office of the U.S. Department of Energy's Office of Energy Efficiency and Renewable Energy under Contract Number DE-AC02-06CH11357. 


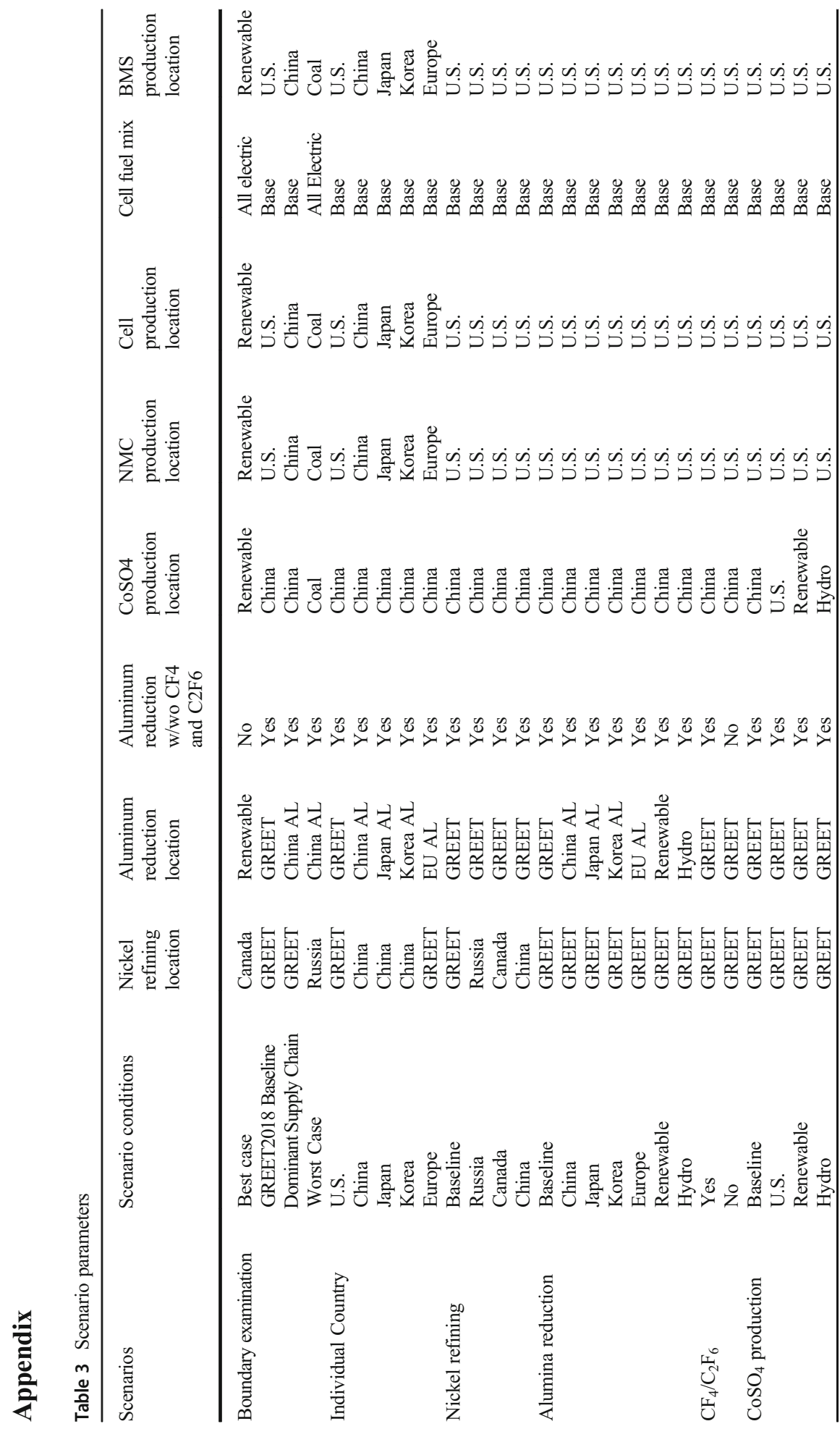




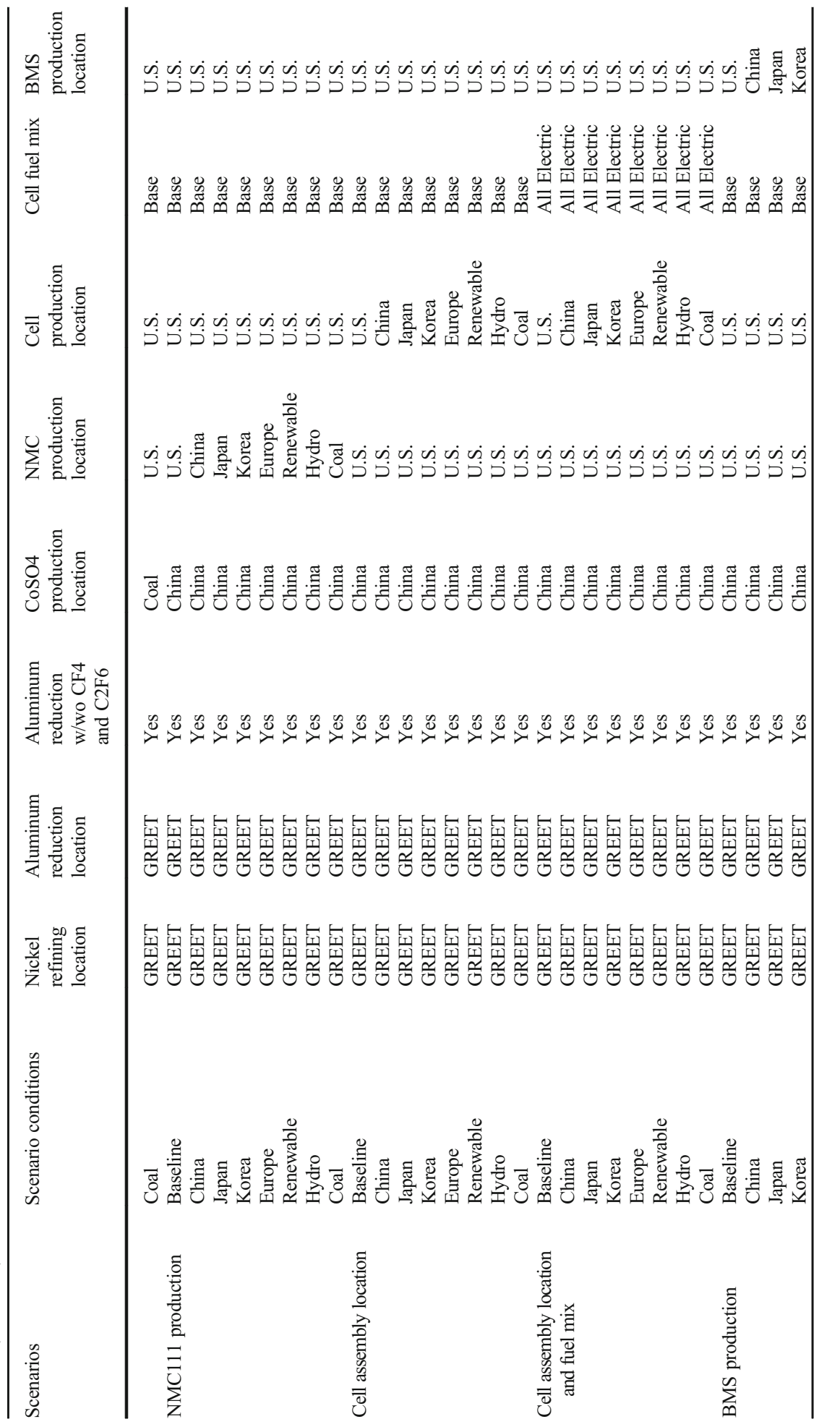




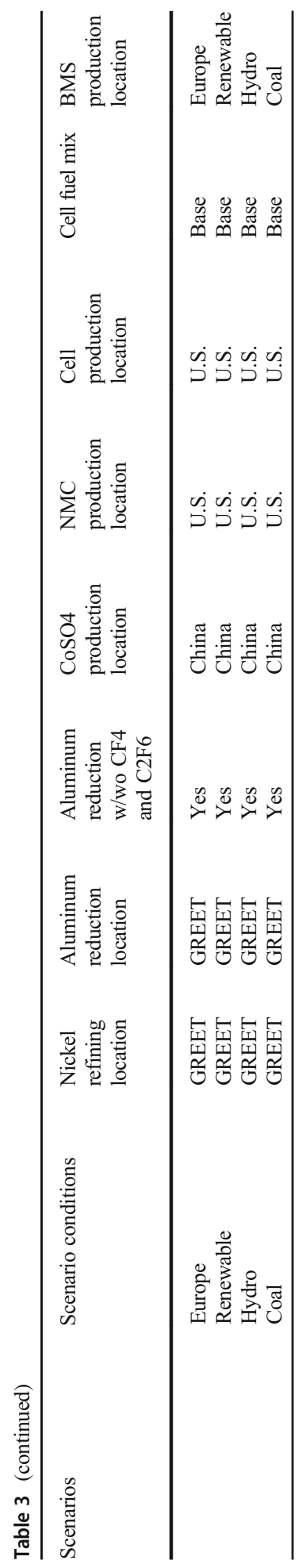




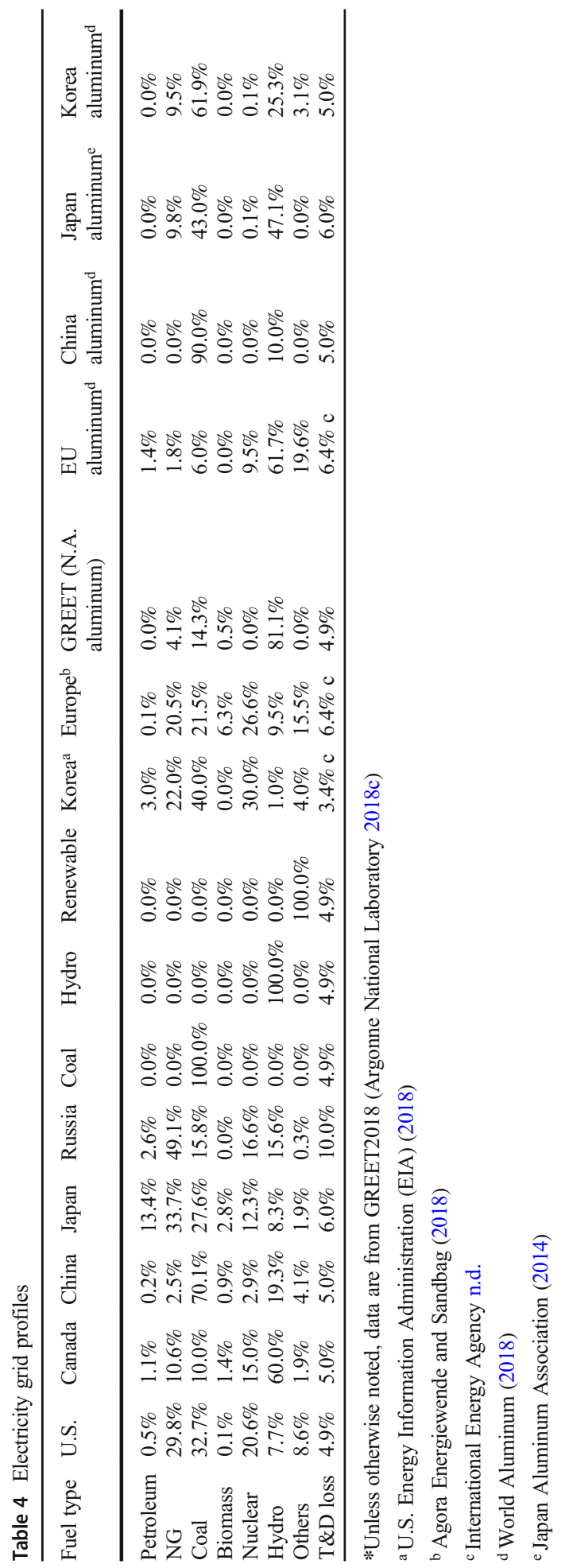


Table 5 Process emissions for nickel refining ( $\mathrm{kg} / \mathrm{kg}$ of product)

\begin{tabular}{lllll}
\hline Country & Canada & China & GREET & Russia \\
\hline $\mathrm{SO}_{\mathrm{x}}(\mathrm{kg} / \mathrm{kg}$ product $)$ & 0 & 0 & 907,185 & $2,902,991$ \\
\hline
\end{tabular}

GREET2018 (Argonne National Laboratory 2018c)

Open Access This article is licensed under a Creative Commons Attribution 4.0 International License, which permits use, sharing, adaptation, distribution and reproduction in any medium or format, as long as you give appropriate credit to the original author(s) and the source, provide a link to the Creative Commons licence, and indicate if changes were made. The images or other third party material in this article are included in the article's Creative Commons licence, unless indicated otherwise in a credit line to the material. If material is not included in the article's Creative Commons licence and your intended use is not permitted by statutory regulation or exceeds the permitted use, you will need to obtain permission directly from the copyright holder. To view a copy of this licence, visit http://creativecommons.org/licenses/by/4.0/.

\section{References}

Ahmed S, Nelson PA, Dees DW (2016a) Study of a dry room in a battery manufacturing plant using a process model. J Power Sources 326:490-497

Ahmed S, Nelson PA, Gallagher KG, Dees DW (2016b) Energy impact of cathode drying and solvent recovery during Lithium-ion battery manufacturing. J Power Sources 322:169-178

Argonne National Laboratory (2018a) BatPaC: A Lithium-Ion Battery Performance and Cost Model for ElectricDrive Vehicles (version 3.1). Argonne National Laboratory. http://www.cse.anl.gov/batpac. Accessed 22 January 2019

Argonne National Laboratory (2018b) “Argonne GREET Vehicle Cycle Model (2018 Version).” October 10, 2018. https://greet.es.anl.gov/greet_2_series

Argonne National Laboratory (2018c) "GREET Models.” October 10, 2018. https:/greet.es.anl.gov/greet.models

Bauer C, Hofer J, Althaus H-J, Del Duce A, Simons A (2015) The environmental performance of current and future passenger vehicles: life cycle assessment based on a novel scenario analysis framework. Appl Energy 157:871-883

Benavides PT, Dai Q, Sullivan JL, Kelly JC, Dunn JB (2015) “Material and Energy Flows Associated with Select Metals in GREET 2. Molybdenum, Platinum, Zinc, Nickel, Silicon.” Argonne National Lab.(ANL), Argonne, IL (United States)

Colett JS, Kelly JC, Keoleian GA (2015) Using nested average electricity allocation protocols to characterize electrical grids in LCA: a case study of U.S. primary aluminum production. J Ind Ecol 20, 1(2016):29-41

Dai Q, Kelly JC, Burnham A, Elgowainy A (2015) Updated Life-Cycle Assessment of Aluminum Production and Semi-Fabrication for the GREET Model. Argonne National Lab.(ANL), Argonne

Dai Q, Dunn JB, Kelly JC, Elgowainy A (2017) Update of life cycle analysis of Lithium-ion batteries in the GREET® model. Argonne National Laboratory (ANL), Argonne, IL (United States)

Dai Q, Kelly JC, Elgowainy A (2018) Cobalt life cycle analysis update for the GREET model. Argonne National Laboratory https:/greet.es.anl.gov/publication-update_cobalt. Accessed 3 February 2019

Dai Q, Kelly JC, Gaines L, Wang M (Submitted) Life cycle analysis of Lithium-ion batteries for automotive applications. Batteries 5, 2(2019):48

Dunn JB, Gaines L, Kelly JC, James C, Gallagher KG (2015) The significance of Li-ion batteries in electric vehicle life-cycle Energy and emissions and Recycling's role in its reduction. Energy Environ Sci 8(1):158-168

Elgowainy A, Han J, Ward J, Joseck F, Gohlke D, Lindauer A, Ramsden T, et al. (2016) "Cradle-to-grave lifecycle analysis of US light duty vehicle-fuel pathways: a greenhouse gas emissions and economic assessment of current (2015) and future (2025-2030) technologies." ANL/ESD-16/7 rev. 1. Argonne National Laboratory (ANL). http://www.osti.gov/scitech/biblio/1254857. Accessed 3 February 2019

Ellingsen LA-W, Majeau-Bettez G, Singh B, Srivastava AK, Valøen LO, Strømman AH (2014) Life cycle assessment of a Lithium-ion battery vehicle pack. J Ind Ecol 18(1):113-124

Energiewende A, Sandbag (2018) The European power sector in 2017. State of affairs and review of current developments. 128/02-A-2018/EN. https://sandbag.org.uk/wp-content/uploads/2018/01/EU-power-sectorreport-2017.pdf. Accessed 7 February 2019 
Faria R, Marques P, Moura P, Freire F, Delgado J, de Almeida AT (2013) Impact of the electricity mix and use profile in the life-cycle assessment of electric vehicles. Renew Sust Energ Rev 24:271-287

Hawkins TR, Singh B, Majeau-Bettez G, Strømman AH (2013) Comparative environmental life cycle assessment of conventional and electric vehicles. J Ind Ecol 17(1):53-64. https://doi.org/10.1111/j.15309290.2012.00532.x

Holland SP, Mansur ET, Muller NZ, Yates AJ et al (2016) Are there environmental benefits from driving electric vehicles? The importance of local factors. Am Econ Rev 106(12):3700-3729

International Energy Agency (2018) Global EV Outlook 2018. https://www.iea.org/gevo2018/. Accessed 23 January 2019

International Energy Agency (n.d.) "Electric Power Transmission and Distribution Losses (\% of Output)." Accessed May 3, 2019. https://data.worldbank.org/indicator/eg.elc.loss.zs

Japan Aluminum Association (2014) “わが国の輸入アルミニゥム新地金のインベントリ 'Inventory of Imported Aluminum Ingots from Japan." Japan Aluminum Association. http://www.aluminum.or. jp/environment/pdf/201403lac1_2.pdf. Accessed 15 March 2019

Kim HC, Wallington TJ, Arsenault $\bar{R}$, Bae C, Ahn S, Lee J (2016) Cradle-to-gate emissions from a commercial electric vehicle Li-ion battery: a comparative analysis. Environ Sci Technol 50(14):7715-7722

Lee U, Han J, Elgowainy A, Wang M (2018) Regional water consumption for hydro and thermal electricity generation in the United States. Appl Energy 210:661-672

Lutsey N, Grant M, Wappelhorst S, Zhou H (2018) Power play: how governments are spurring the electric vehicle industry. White Paper. https://theicct.org/publications/global-electric-vehicle-industry. Accessed 10 April 2019

Majeau-Bettez G, Hawkins TR, Strømman AH (2011) Life cycle environmental assessment of Lithium-ion and nickel metal hydride batteries for plug-in hybrid and battery electric vehicles. Environ Sci Technol 45(10): 4548-4554

McMillan C, Keoleian GA (2009) Not all primary aluminum is created equal: life cycle greenhouse gas emissions from 1990 to 2005. Environ Sci Technol 43:1571-1577

Mudd GM (2010) Global trends and environmental issues in nickel mining: sulfides versus laterites. Ore Geol Rev 38(1):9-26

Nealer R, Reichmuth D, Anair D. (2015) Cleaner cars from cradle to grave: how electric cars beat gasoline cars on lifetime global warming emissions. Union of Concerned Scientists Report. https://www.ucsusa. org/sites/default/files/attach/2015/11/Cleaner-Cars-from-Cradle-to-Grave-full-report.pdf.Accessed 3 February 2019

Notter DA, Gauch M, Widmer R, Wager P, Stamp A, Zah R, Althaus H-J (2010) Contribution of Li-ion batteries to the environmental impact of electric vehicles. Environmental Science \& Technology. 44(17):6550-6556

Olivetti EA, Ceder G, Gaustad GG, Fu X (2017) Lithium-ion battery supply chain considerations: analysis of potential bottlenecks in critical metals. Joule 1(2):229-243

Onat NC, Kucukvar M, Tatari O (2015) Conventional, hybrid, plug-in hybrid or electric vehicles? State-based comparative carbon and Energy footprint analysis in the United States. Appl Energy 150:36-49

Peterson SB, Whitacre JF, Apt J (2011) Net air emissions from electric vehicles: the effect of carbon price and charging strategies. Environmental Science \& Technology 45(5):1792-1797

Pillot C (2018) The rechargeable battery market and Main trends 2017-2025. Presented at the 35th Annual International Battery Seminar \& Exhibit, Fort Lauderdale, FL, USA, March 26

Stephens T, Zhou Y, Burnham A, Wang M (2018) Incentivizing Adoption of Plug-in Electric Vehicles: A Review of Global Policies and Markets. Argonne National Lab.(ANL), Argonne

U.S. Energy Information Administration (EIA) (2018) Country Analysis Brief: South Korea. https://www.eia. gov/beta/international/analysis_includes/countries_long/Korea_South/south_korea.pdf. Accessed 23 January 2019

U.S. Geological Survey, McRae ME (2018) 2105 minerals yearbook: nickel. U.S. Department of the Interior. https://www.usgs.gov/centers/nmic/nickel-statistics-and-information. Accessed 24 January 2019

Wang MQ (1999) GREET 1.5 - transportation fuel-cycle model - volume 1: methodology, development, use, and results. ANL/ESD-39 Vol. 1. Argonne National Laboratory. http://inis.iaea.org/search/search.aspx?orig_q= $\mathrm{RN}: 32046222$. Accessed 23 January 2019

Wood III, David L, Li J, Daniel C (2015) Prospects for reducing the processing cost of Lithium ion batteries. J Power Sources 275:234-242

World Aluminum (2018) "Primary Aluminium smelting power consumption." December 7, 2018. http://www. world-aluminium.org/statistics/primary-aluminium-smelting-power-consumption/

Publisher's note Springer Nature remains neutral with regard to jurisdictional claims in published maps and institutional affiliations. 